\title{
ONCE UPON A PLACE-NAME: \\ DIVERSIFYING APPROACHES TO ONOMASTICS IN SCOTLAND
}

\author{
SARAH KÜNZLER \\ University of Glasgow
}

\section{INTRODUCTION}

This special issue arose from two workshops held at the University of Glasgow in May 2019 and January 2020, but it represents the accumulation of months rather than hours of intense dialogues. ${ }^{1}$ It is therefore fitting to start this introduction with thanks to the many people who kindly shared their thoughts with us. Above all, the assistant editor, Simon Taylor, guided this project through his wisdom, his experience and his humour - qualities that were greatly appreciated, especially since the majority of the editorial work took place during the COVID-19 pandemic. At the second of these events, a diverse and inquisitive audience generously provided feedback and stimulating questions and this volume is much richer for their insights. Others could not attend the workshop but nonetheless provided encouragement and guidance at various points. ${ }^{2}$ Along the line, the anonymous reviewers of the articles also pointed out useful points for further investigation. To all of these colleagues and friends, the contributors and I express our gratitude.

My own research on the mnemonic role of landscapes and places in medieval Irish cultural memory provided the initial interest in topics of placemaking and space-making, yet the breadth of knowledge in these pages shows the prevalence of such issues across the humanities (and beyond). While my original interest pertained to the pre-modern era, conversations with colleagues working on modern sources raised many new questions, not least about the temporal depth of the issues we discuss. In medieval Irish literature, both placenames and the associated place-lore can reference monuments or natural features that ostensibly provide material 'proof' that a (often fantastical) story

1. I would also like to express thanks to The British Academy and the Centre for Scottish and Celtic Studies, University of Glasgow, who kindly funded these events.

2. These include my project mentor, Geraldine Parsons, Katherine Forsyth, who first sowed the seeds for a special issue project, Emily Lethbridge, Kay Muhr, Stephen Driscoll and Stephen Harrison, whom I had the pleasure of meeting on various occasions. Special thanks also goes to Liam Ó hAisibéil, who further kindled my interest in the use of place-names in medieval literature. 
happened, and that it happened right here. For example, in Mesca Ulad (The Intoxication of the Ulstermen'), the Ulstermen go astray in foreign territory on their journey home after a drinking bout. When they are surprised by snow, they build shelters for their horses: they 'raised stone columns to shelter their horses, between them and the snow; so that the echlasa of the horses of Ulad remain still, from that time to this. And these are the tokens of the story' (Hennessy $1889,17){ }^{3}$ Gregory Toner $(2018,68)$ stresses that the 'assertion that they could still be seen at the time of writing suggests that they actually existed, and so the story neatly accounts for the surviving monument'. The material world which the medieval (and even modern) Irish inhabit therefore relates intimately to such stories. Although no place-name is created in the example cited above, other texts such as the early thirteenth-century Acallam na Senórach ("The Colloquy of the Ancients') make frequent use of linking place-names to stories, for example in the case of Ráith Áine ('the fort of Áine'; Dooley and Roe 1999, 93-94).

Through re-analysis and folk etymology rather than direct transmission, modern folklore shows a similar engagement with places and place-names and hence with the connection between past and present, name and place, human beings and the landscape. It is these connections, along with the social and cultural use of place-names, that are explored from various angles in this special issue. My role as guest editor and project coordinator was to facilitate exchanges across disciplinary, linguistic and temporal boundaries. I also hope to have created a balance between the particular and the universal, between theoretical thinking and source-work, and to have provided a space in which each case study could explore such interactions in its own particular environment.

The special issue covers both the pre-modern period - in the joint article by Anouk Busset and Sofia Evemalm-Graham and the contribution by Alasdair C. Whyte - and the modern period, reflected in the articles by Alison Burns and Leonie Mhari. A fifth contribution, by Jake King, also engaged with pre-modern and early modern sources, studying romances and early maps to examine the origin and development of select Gaelic exonyms. His aim was to identify a number of Gaelic place-names mentioned in these stories and romances that were once evidently actual places, but whose location over time became lost and the names were then adopted as 'stock names' for usage in narratives.

3. Echlasa (pl. of echlas/echlais) denotes shelters for horses or cattle: http://dil.ie/19524 accessed 25/9/2020. 
Unfortunately, the circumstances surrounding the COVID-19 pandemic made it impossible for this study to be included in this year's special issue. Nonetheless, the four case studies published here cover the best part of a millennium and show the prevalence and chronological depth of the issues with which we are engaging.

Although they are diverse in many ways, the articles all engage with approaches that expand traditional onomastic research and show the vibrancy and innovation in current Scottish onomastics. This is not to say that the classic tools of onomastic research - collection of place-names through field-work and the analysis of maps and historical documents, etymologising, and contextualising the place-names in geographical and topographical terms - are disregarded. These tools provide a sound basis for further analyses. Yet the traditional methods for analysis and the sole focus on finding the earliest attested source together with the correct etymology do not always allow us to capture the ongoing human engagement with these place-names; an engagement that can lead to re-analysis of a name and folk etymologies, or that may draw on everyday experiences rather than on historically accurate information about a place. How we as researchers (and human beings) come to know about these processes of experiencing and 'using' a place(-name) is a question that all of the following articles address to varying degrees. The research therefore acknowledges the inconsistencies and variances in the sources, perceiving these as part of 'living with place-names' rather than simply as unfortunate circumstances surrounding transmission. This stance also underlines the not insubstantial question of the context in which the sources were produced and how place-names and place-lore were/are collected; not least in the case of field-work being conducted today, as Alison Burns' article outlines.

A broad outlook is further represented in the Scottish places that the contributors chose to discuss. These are as geographically and contextually diverse as coastal features on the isle of Mull (Alasdair C. Whyte), field-names in Aberdeenshire (Alison Burns), coastal places in Berwickshire which were important primarily for the fishing community (Leonie Mhari) and the religious landscape of Glen Lyon (Anouk Busset and Sofia Evemalm-Graham). The landscapes provide very different contexts for coining and experiencing names, from the very practical need to navigate the waters safely (and profitably!) when out fishing to associations with one of the most powerful early Christian centres of Britain and Ireland, Iona. It is thus hardly surprising that the sources which 
the contributors utilise in their studies are equally diverse. While Ordnance Survey Name Books and maps are a staple of onomastic research, the contributors also rely on more varied (re)sources - their own collections of (sometimes otherwise unrecorded) microtoponyms, archaeological excavations, geological formations, songs, and folklore. ${ }^{4}$ These sources in turn emphasise the complex cultural and linguistic make-up of modern Scotland, with place-names in Gaelic, Scots, and English being discussed and a reference made to a probable Pictish place-name (Peallaidh). Rather than constricting the approaches through shared research questions or temporal or spatial limitations, the plurality of regions, sources, topics and methods employed in this special issue reflect our collective desire to study multiple contexts of placename-making (and place-name-use) with regard to how it makes visible the relationship between the 'namer' and the 'named'. The arrangement of the articles in this special issue follows a progression from west (Muile/Mull) to east (the Berwickshire coast), utilising geographical space to order the pluralistic overlaps between the studies.

\section{WHAT'S IN A PLACE?}

For a long time onomasticians have asked 'what does this (place-)name mean?', and 'what can it tell us about the period in which it was coined?' Landscape scholars and archaeologists, on the other hand, have ventured to enquire about the complementary question of 'what does this place mean?', a question which in recent times increasingly incorporates the re-uses of places over the centuries. But it is only recently that the two groups have begun a serious dialogue about their shared interest in places. Yet if we are considering placenames in their social and cultural as well as their material, practical, geographical and topographical context, both of these questions must be addressed. A suitable starting point might be to consider the complex 'cultural

4. The last of these terms caused considerable discussion at the workshops, as it was felt that it had all too often been used in a derogatory manner in previous research - a perspective which we do not share and which we did not want to reiterate. Rather than incorporating a value judgement or a clear idea who 'the folk in folklore' are, the term is used here loosely as denoting stories that reveal a local engagement with places but which are not (necessarily) the product of a learned or elite group of society, but commonly shared amongst several social strata. For a more detailed discussion see the contribution by Anouk Busset and Sofia Evemalm-Graham. 
work' that place-names do, and to acknowledge the wealth of information about life in the Scottish landscape which the place-names discussed here can provide: how people made a living from the land, how they related to previous generations (and even mythical figures) inhabiting the land, how they codified danger, power and belonging, what flora and fauna surrounded them, how they utilised the landscape for fishing and farming, and what belief systems they practiced. Many of these questions can be (and are) posed both for the time in which a toponym was coined as well as for their development and reinterpretation over the centuries.

Ignoring such issues would have run the risk of detaching the place-names not just from their places but also from the people who coined and used them. Striking a balance between the practical and the symbolic, however, can entail utilising a broader variety of sources than those discussed in more traditional onomastic research - a challenge to which the approaches taken here bear testimony. This illustrates the observation that toponyms serve multiple functions, for example

making use of natural resources when they reflect natural characteristics, in cultural transformation of the geographical space when they shape it both visually and mentally as well as in identity building with individual members of a cultural group and with a cultural group in total when place names function as labels and support emotional ties between man and place (Jordan, 2012, 117)

Jordan therefore proposes that both individuals and larger groups engage with place-names on various levels: to experience emotional ties to a place, to label natural resources and to see places reflecting their cultural identity, for example by linking them to mythical figures or saintly exploits. The contributions address all of these functions, albeit to different degrees and relying on the context of the sources.

That such conversations are starting to become more frequent is thanks in no small part to the Cognitive Toponymy Project, a collaboration between the Universities of Glasgow, St Andrews, and Copenhagen, led by Prof. Carole Hough of English Language and Literature, University of Glasgow. ${ }^{5}$ The project investigated the complementary role of human cognition in the

5. See https://cogtop.org/en/(accessed 22/7/2020). 
conceptualisation(s) of place(-names) and hence addressed the question of how place-names are indebted to the human perception of the world. ${ }^{6}$ This outlines that our engagement with places is not neutral, but a reflection of our frames of knowledge and our way of life. This issue is raised at length in the contributions by Leonie Mhari and Alison Burns, which link practical and cognitive aspects of place-name research. Yet as frames of knowledge and the use of the landscape change it increasingly becomes apparent that neither a place-name nor the meaning or use of a place(-name) are (necessarily) static, an observation that necessitates an engagement with the different 'strata' of meaning codified in toponyms.

This change in research paradigm was popularised by W.F.H. Nicolaisen (2002, 1991, 1976), who combined folklore studies and onomastic research and hence in many ways prefigured the approaches followed in this special issue. His studies turned 'from an initial preoccupation with the product - the name, via fascination with the process - naming, to an infatuation with the producer - Man' (Nicolaisen 1976, 158). After all, Nicolaisen (1991, 9) concludes: 'homo narrans and homo nominans are, indeed, the same people responding to the same intellectual stimuli, essential and existential for the survival of homo sapiens - narrating and naming, telling stories and structuring the world around us through the imposition of names'. In this context, this special volume builds on, and expands, this change in focus, as it discusses the relationship between the product (a name), the process of naming, humans, and the (social, cultural and material) environment in which humans live(d). It also actively acknowledges women as producers, both as researchers and in name-giving, as the article by Alasdair C. Whyte explores. Such an interest in both human and non-human 'actors' is prevalent in modern landscape studies and landscape archaeology (e.g. in the work of Barbara Bender 2006, 2002, 2000; Denis Cosgrove 2008; Christopher Tilley 2006, 1994) and has been used productively in Scandinavian Studies (e.g. Emily Lethbridge 2016; Matthias Egeler 2018, 2015; Terry Gunnell 2009; Gísli Sigurðsson 2018). It is on this type of research that many of the conversations at the first workshop focussed, and this interest is well represented across the special issue, from Alasdair C. Whyte's discussion of

6. Two of the project members have kindly contributed to this volume: Alison Burns through an article, and Simon Taylor as assistant and advisor. The project has greatly influenced much current research at the University of Glasgow, including my own. 
the Cailleach-related place-names on Mull to the associations of St Adomnán with Glen Lyon (Sofia Evemalm-Graham and Anouk Busset's joint article).

Yet despite an increased focus on place-making and place-use, the vexed question of what a place is proves elusive across disciplines, and it remains to be seen what perspective toponymic research can contribute to this dialogue. Yet especially for interdisciplinary approaches and collaborations, it is important to at least briefly pause to ask how the term is used in individual disciplines. In The Dictionary of Human Geography, George Henderson (20o9, 539) offers the following distinction:

In a generic sense, a place is a geographical locale of any size or configuration, comparable to equally generic meanings of area, region or location. In human geography and the humanities more generally, however, place is often attributed with greater significance. It is sometimes defined as a human-wrought transformation of a part of the Earth's surface or of pre-existing, undifferentiated space.

During the gestation of this special issue, these observations provided an interesting impetus for framing our approaches to place(-making), as did Henderson's addendum $(2009,539)$ that places 'reflect cultural perceptions and habits, they are always in a state of becoming, and they are part both of the perception of individual human subjects and power-laden social relations'. While no concise definition of place is used throughout this issue (and to agree on one is a difficult endeavour in any case), the importance of cultural, social, and/or subjective attribution of meaning to a particular locale characterises the analytical use of the term 'place-name' by the contributors.

In addition, landscapes and their diverse uses proved a central point for discussion during the workshops, not just because places are always embedded in them but also because at the time many of the place-names discussed here were coined, human beings were directly dependent on 'their' landscape. Especially in previous centuries, many people lived in (and off) the land(scape) as much as they inhabited a particular place. Landscapes are therefore at once material, spatial and practical as well as 'a milieu of cultural practise and values' (Wylie 2007, 5). But as the contributions to this special issue show, cultural practices can also include mundane every-day tasks, and both may need to be considered in the dynamic toponomatic research propagated here. For, as Denis E. Cosgrove $(2008,18)$ summarises for American landscapes, 'landscapes 
emerge from specific geographical, social and cultural circumstances' and are 'embedded in the practical uses of that physical world as nature and territory, while its intellectual shaping in America (...) has drawn upon deep resources of myth and memory'. The contributions to this volume acknowledge the dynamic - and often multifaceted and fluid - engagement with landscapes, places and place-names, leading to the assumption that 'reading landscapes can reveal both symbolic systems of meaning [and] the social relations in societies' (Jones 2012, 85), and even the role of holy, mythical and non-human actors in the shaping of locales such as Glen Lyon. This comes to the fore in the contributions by Sofia Evemalm-Graham, Anouk Busset and Alasdair C. Whyte. Leonie Mhari offers yet a different perspective by discussing weathering and water and thus provides a stark reminder that natural elements are important to consider, especially in cognitive toponomy.

\section{BEING IN A PLACE: PAST AND PRESENT}

Even if most of us do not have the luxury of dwelling in the places that we research, we can assume that the places, place-names and place-lore which we study are (by and large) the result of such dwelling. Mark Edmonds $(1999,7)$ stresses the importance of considering dwelling when he argues that ' $[\mathrm{c}]$ rucial to much recent research has been the idea that people do not think about their world in the abstract, or even gaze at it like some painting in a frame. Rather, they experience it physically'. While the physical experience of a place underlies all of the case studies presented here, there are other ways of experiencing named locales which are also taken into account. Tilley $(1994,18)$, for example, proposes that naming involves the transformation of 'the sheerly physical and geographical into something that is historical and socially experienced'. Such experiences are extant in the frequent cognitive associations of landscape features - such as rocks - with humans or animals (or their body parts), as is discussed in Leonie Mhari's article. The association of places in Glen Lyon with the protective hand (or foot) of St Adomnán are explored in the article by Anouk Busset and Sofia Evemalm-Graham, which, however, openly acknowledges the difficulties in correlating archaeological and toponomastic evidence for the Glen. ${ }^{7}$ A complementary picture might emerge from the

7. The footprint (often associated with St Adomnán) in particular, invites even the modern visitor to compare shoe-sizes! A wholly different issue would have been discussed in the contribution by Jake King (see pp. 2-3) which would have highlighted 
features associated with the Cailleach on Mull, examined in Alasdair C. Whyte's article. Here it is a mythical figure from medieval Gaelic literature and folklore that provides associative power, and perhaps helps to signal particularly dangerous waters. In the articles, it therefore becomes apparent that metaphorical and/or cognitive readings and practical use are by no means mutually exclusive. Place-names could simultaneously function as road signs or even warning signs (clearly an invaluable help for safely navigating routes in a period before modern road or waterway systems and governmental signage) to marking a place as home, and anything in between.

The fact that individual place-names may be used over centuries alerts us to the contextualised, at times even personal, response to places, place-names and landscapes. As Bender (2006, 303) phrases it, '[t]he same place at the same moment will be experienced differently by different people; the same place, at different moments, will be experienced differently by the same person; the same person may even, at a given moment, hold conflicting feelings about a place'. The destabilisation of static concepts of places and landscapes has transformed recent landscape studies. As Bender (2000, 24) concludes,

Some people may well be uneasy with the idea of landscape (and, indeed, people's sense of place and identity) as something fluid, relative, and context dependent. (...) And they are right, - it is 'out there' and it has been shaped, but the point is simply that what is there, and what has been done, is always experienced through our sensibilities and actions. And these, in turn, hinge upon our social relationships and cultural perceptions. And these are always historically specific.

This was a central point for discussion amongst the contributors, and it also led to debates as to how far the current focus on 'cultural landscapes' is a suitable area for analysis in onomastic research (at least for the modern period). The contributions answer this question differently, and stress the importance of utilising source-driven case studies (rather than broad theoretical frame-works) to investigate such issues. For example in Alasdair C. Whyte's study of the Cailleach place-names of Mull, it becomes evident how a figure from medieval Gaelic literature and folklore can continue to be meaningful as a cultural

the conceptualisation of places in the wider world. Such a juxtaposition between the 'local' and the 'global' is a timely reminder that place-name discourses span a wealth of sources, and that individual circumstances need to be acknowledged in each study. 
coordinate even in modern songs. Yet Alison Burns' article shows that in frequently reflecting the current use of a field or farming equipment, fieldnames can be subject to the changing use of landscape. Here, experience and response must be read in a primarily practical context. Capturing the human engagement with change and the context of name-giving and name-change, Burns presents an insightful case study into the more pragmatic - but at times no less emotional - use of place-names in rural societies. Leonie Mhari's article outlines the vast ground in-between, where practical and metaphorical responses overlap in the narratives associated with coastal names in Berwickshire.

The changed use of the landscape today from the time at which the names were coined, as well as the impact which previous landscape use had both on the landscape and on the namescape, was a prevalent topic at the workshops. At a time when cultivating and navigating land and sea were integral for human survival - e.g., knowing what would grow in a specific field, and where fish could (relatively safely) be caught - the every-day use of the landscape was clearly a prime concern for what was named, and how it was named. Simon Taylor (2016, 69 ) asserts that

in Europe over the past 1,0oo years there has been a distinct move away from an almost complete dependence on the immediate environment for sustenance and other basic needs to one where international trade, manufacture, services, and state support have come to dominate. This shift is reflected in the way, and what, humans choose to name.

The issue is discussed by Leonie Mhari in relation to specific coastal placenames reflecting shelters for animals (Goose Craves and Pikie's Stell), where farm animals in particular but also other fauna provide cognitive reference points for naming. This suggests that the home of the name givers can transcend that environment and be projected onto coastal stretches of land, testimony to an intimate relationship between cognitive toponymy and practical life. In Alison Burns' article, the naming of Aberdeenshire field names clearly reflects technical development and changes in working practices, an issue that is at times openly addressed by her informants. In this sense, the research presented here challenges rigid boundaries between the cognitive and the practical or between the metaphorical and the material, and shows that the engagement 
with the landscape is multi-layered and pluralistic, and that toponomastic research can highlight this in its approaches.

A useful observation about how landscape uses reflected in place-naming are then transmitted into toponomastic databases was made by Séamas Ó Catháin and Patrick O'Flanagan $(1975,245)$. In their intimate study of the placenames of Kilgalligan (Co. Mayo) they assert that

Virtually anything which has some relevance to the lives and activities of people, ranging from topographic features to the presence of particular kinds of animals or plants and also many items of human construction, such as bridges and pathways, has been named. It is unlikely that any single individual in the townland knows every name there, or indeed, every name in this extensive collection, though those who combine the jobs of fishermen and farmers are more advantageously placed than others, in that their daily tasks bring them into constant contact with many different parts of the townland. Factors such as age, sex and major occupations will also generally tend to determine which people know and use which names. Women and children also possess a keen awareness of the names of places, especially those associated with their day to day activities; such places, for example, as sheltered areas where clothes can be washed and dried, and also all the sources of water in the townland.

Their observations are a vital reminder that factors such as socio-economic status, profession, nativeness, gender and age can all influence not just our use of place-names, but also the collection of place-names. This is discussed by Alison Burns who acknowledges that in her research, knowledge about fieldnames was shared more frequently by a specific gender (male farmers), but that this does not mean that other members of the group do not possess (at times complementary or conflicting) information. Furthermore, Alison Burns' own experience as a young, female researcher collecting field-names from much older male informants also functions as a timely reminder to consider the collection process (and possible issues) in current place-name collections. On a complementary level, the article by Anouk Busset and Sofia Evemalm-Graham shows that earlier collectors could at times confuse places and place-names. This highlights the importance of intimate knowledge about the place's 
geographical (and cultural) context, but is also a call to openly acknowledge such problems in our own research.

The workshops also addressed the substantial issue of how we work with traditional sources, and critically examined the nature and collection-practices of our sources: what appears on a map, on an official document or in the Ordnance Survey Name Books is frequently perceived as the (only) valid name. ${ }^{8}$ Yet local inhabitants might have different, more or fewer names for the places they navigate on a daily basis and these too are worth considering. Similarly, official documents might record a place-name that was not in use with the local population but solely with figures of authority, or the explanation of a place in any given document might reflect particular political, religious, or local agendas, ignoring different explanations and discourses. And, as Simon Taylor stressed during the second workshop, we may also have to consider how maps and official documents - in fact any written source - can act as a brake on the evolution of a place-name, resulting in differing forms of a name in spoken and the written discourse. By acknowledging the perspectives and context evident from the sources, and by including novel sources such as folklore (Sofia Evemalm-Graham) and song (Alasdair C. Whyte), this special issue stresses that place-names are communicated both through the voices of the powerful and those without power. To capture such variation, it to some degree focuses on all of the variables common to socio-linguistic research: age, gender, ethnicity, socio-economic class, lifestyle, nativeness (Ainiala and Östman 2017, 8).

This clearly reflects Bender's broader statement that 'the engagement with landscape and time is historically particular' and that this engagement reflects 'social relations' and is 'deeply political' (Bender 2002, 104). Questions such as who names a place, when, for what purpose (or from which perspective), and

8. The question of who was consulted for the OS maps was addressed at the second workshop. To my current knowledge, no surveys exist to provide detailed information about this. However, the assistant editor, Simon Taylor, kindly brought it to my attention to the fact that in The Place-names of Fife (vol. 5), he and his co-author Gilbert Márkus address precisely this issue $(2012,144)$ : It is commonly stated that the Ordnance Survey consulted only the landed and middle classes in their establishment of correct name-forms, but in fact the main criterion for selection, at least for Fife and Kinrossshire, seems to be familiarity with the locality. In Column iv, lairds, schoolmasters, ministers and factors rub shoulders with foresters and other labourers, and in the case of habitations, however lowly, one of the informants is usually the occupier or tenant.' See also Williamson (2015). 
how this place-name is transmitted in sources, collected, or used in everyday life become important, even if such questions often cannot be answered conclusively. Yet simply voicing such issues challenges many previous assumptions on the neutrality of sources - a challenge which in essence is indebted to much larger questions of aetiology and human knowledge.

These thoughts, though naturally sketchy in nature, summarise the main areas with which the articles engage and the topics which we discussed in our meetings. Each one of the contributors here brings unique skills and outlooks to the special issue, and each will formulate different angles on these topics. The topics and approaches introduced here prompt a dialogue with folklore studies (folk onomastics), sociology (socio-onomastics), local and national history, earth sciences and cognitive sciences and it is hoped that these disciplines will increasingly collaborate with onomasticians in the future.

After all our efforts, we may be no closer to offering a concise answer to what is in a name or in a place. Yet I hope that we have succeeded in delineating individual human engagement with places and landscapes by discussing some of the roles place-names and places play in identity formation (from the microto the macro-level). It is hoped that a multitude of voices are heard in these contributions, both from the young researchers sharing their insights and from groups and sources which, traditionally, were not well represented in onomastic source material. As a project coordinator and guest-editor of the issue, I relished the fact that a multitude of ways for approaching place-(names) became evident, bound together by recurring themes: perspectives, authority and power, and the dynamic nature of places, landscapes, and traditions. I hope the diversity is also evident from this introduction, which refrains from directing the reader towards one particular understanding of place(names) or reducing the articles to mere summaries. Ultimately, I hope we have succeeded in bringing Scottish place names - and the research on them - into a broader dialogue. I hope also that it will prompt readers of this volume to join the discussion and to think about how they interact with the places which they inhabit, use and research. Finally, I hope that it will prompt an exchange of thoughts with those who have engaged with similar issues from different points of view. Perhaps future dialogues will emerge from that, dialogues that allow us to more fully acknowledge the complexities of both onomastic research and places. 


\section{REFERENCES}

Bender, Barbara, 2000, 'Investigating Landscape and Identity in the Neolithic', in Neolithic Orkney and its European Context, ed. Anna Ritchie, McDonald Institute of Archaeological Research (Cambridge), 23-30.

Bender, Barbara, 2002, 'Time and Landscape', Current Anthropology 43, 103-112. Bender, Barbara, 2006, 'Place and Landscape', in Handbook of Material Culture, ed. Christopher Tilley, Keene Webb, Susanne Küchler, Mike Rowlands and Patricia Spyer (London), 303-314.

Dooley, Ann, and Harry Roe, transl., 1999, Tales of the Elders of Ireland (Oxford). Cosgrove, Denis E., 2008, 'Introduction to Social formation and symbolic landscape' in Landscape Theory, ed. Rachael Ziday DeLue and James Elskins (London and New York), 17-42.

eDIL: Dictionary of the Irish Language based mainly on Old and Middle Irish examples (Dublin: Royal Irish Academy, 1976); electronic version (eDIL) online at $<$ dil.ie $>$.

Edmonds, Mark, 1999, Ancestral Geographies of the Neolithic. Landscapes, Monuments and Memory (London and New York).

Egeler, Matthias, 2015, 'Reading Sacred Places: Geocriticism, the Icelandic Book of Settlements, and the History of Religions', Philology 1, 67-9o.

Egeler, Matthias, 2018, Atlantic outlooks on being at home. Gaelic Place-Lore and the Construction of a Sense of Place in medieval Iceland, Folklore Fellows' communications 314 (Helsinki).

Gísli Sigurðsson, 2018, 'Mental Maps', in Handbook of Pre-Modern Nordic Memory Studies ed. Jürg Glauser, Pernille Hermann and Stephen Mitchell (Berlin), 66o-665.

Gunnel, Terry, 2009, 'Legends and Landscape in the Nordic Countries', Cultural and Social History: The Journal of the Social History Society 6/3, 305-322.

Henderson, George, 2009 (5th edition), 'Place' in Dictionary of Human Geography, ed. Derek Gregory, Ron Johnston, Geraldine Pratt, Michael Watts and Sarah Whatmore (Chichester), 539-541.

Hennessy, William M., [ed. and transl.], 1889, Mesca Ulad or The Intoxication of the Ultonians, Todd Lecture Series 1.1 (Dublin).

Jones, Andrew, 2012, Human Geography: The Basics (London and New York). Jordan, Peter, 2012, 'Place-Names as Ingredients of Space-Related Identity', in Names and Identities, ed. B. Helleland, C.-E. Ore, and S. Wikstrøm, Oslo Studies in Language 4(2), 117-131. 
Lethbridge, Emily, 2016, 'The Icelandic Sagas and Saga Landscapes: Writing, Reading and Retelling Íslendingasögur Narratives', Gripla XXVII, 51-92.

Nicolaisen, W. H. F., 1976, 'Place-Name Legends: An Onomastic Mythology', Folklore 87.2, 146-159.

Nicolaisen, W. H. F., 1991, "The Past as Place: Names, Stories, and the Remembered Self', Folklore 102, 3-15.

Nicolaisen, W. F. H., 2002, 'Narrating Names', Folklore 113, 1-9.

Taylor, Simon, 2016, 'Methodologies in Place-Name Research', in The Oxford Handbook of Names and Naming, ed. Carole Hough (Oxford), 69-89.

Taylor, Simon, with Gilbert Márkus, 2012, The Place-Names of Fife, Vol. 5, Discussions, Glossaries and Edited Texts (Donington).

Tilley, Christopher, 1994, A Phenomenology of Landscape (Oxford).

Tilley, Christopher, 2006, 'Introduction: Identity, Place, Landscape and Heritage', Journal of Material Culture 11.1/2, 7-32.

Toner, Gregory, 2018, 'Myth and the Creation of Landscape in early medieval Ireland', in Landscape and Myth in Nord-Western Europe, ed. Matthias Egeler (Turnhout), 79-97.

Williamson, Eila, 2015, "Hence the Name": Berwickshire parishes along the Anglo-Scottish Border as described in the Ordnance Survey Name Books', The Journal of Scottish Name Studies 9, 83-96. 